\title{
ASSESSMENT OF COMPETITIVENESS OF THE EU EXPORT IN SERVICES
}

\author{
JOANNA STEFANIAK, ${ }^{1}$ IWONA BĄK ${ }^{2}$ \\ ${ }^{1}$ University of Gdańsk, POLAND \\ e-mail: jstefaniak@ug.edu.pl \\ ${ }^{2}$ West Pomeranian University of Technology Szczecin, POLAND \\ e-mail: ibak@zut.edu.pl
}

\section{RECEIVED \\ ACCEPTED \\ JEL \\ CLASSIFICATION \\ KEYWORDS}

ABSTRACT
18 August 2017

15 December 2017

C38, F14, L80, O5

services, export, competitiveness, European Union, multivariable analysis

The importance of trade in services is growing. However, the European Union's competitive position in the global export of services is worsening in favor of the US and Asian countries. Therefore the importance and future of the EU and its Member States position in the export of services depends on their competitiveness. Therefore the aim of the article is to assess the diversification of the competitive position of the EU Member States regarding the export of services for the 2008-2015.

Differences between European Union countries affects their competitiveness of export in services. The analysis confirmed the great diversity between them. The authors by using the multivariable analysis found out that there was no definite leader in terms of overall competitiveness of export in services throughout the period considered. However four countries could be identified as leaders as they occupied top positions in the respective years, while other four used to have the lowest rankings. Ranks of the rest of the analyzed countries differed, and these differences in some cases were quite significant.

\section{Introduction}

Traditionally services were perceived untradeable contrary to goods (Fuchs, 1968) due to their nature and limitations of traditional modes of trade (Copeland, Mattoo, 2008; Lennon, 2008). The technological development have contributed to the reduction of some limitations (Freund, Weinhold, 2002). As a result some services could be provided at a distance and international trade in services increased. 
Secondly, the efforts to liberalize trade in services in international dimension (WTO/GATS, the EU Services Directive) contribute strongly to its development, but simultaneously lead to greater competition in international markets. Unfortunately, the EU's competitive position in global export of services is worsening in favor of the US and Asian countries, especially China and India. In such a situation, the future and importance of the EU and its Member States in the export of services depends on their competitiveness.

The aim of the article is to assess the diversification of the EU Member States' competitiveness regarding export of services. In order to that two questions are discussed: 1) how the main factors influencing competitiveness of export in services depict the situation in the EU; and 2) how the EU Member States are ranked due to their competitiveness of export in services and how these ranks changed over the analyzed period.

Linear ordering of countries was performed using a method based on Weber median, and typological groups were isolated using the three median method. The construction of rankings and typological groups are preceded by an analysis of competitiveness measures regarding export in services for the EU countries. The Weber median was calculated in R program I1median pakiet pcaPP. Data for 2008-2015 are obtained from the World Trade Organization (WTO) database, Eurostat, the World Bank and other available databases.

\section{Analysis of hasic measures of competitiveness regarding export in services}

Generally competitiveness in international trade is a measure of a country's advantage or disadvantage in selling its products on international markets (OECD, 2005). There are many factors that affect competitiveness, among them changes in productivity, skills and technological knowledge, the nature of public policies, the capacity to raise exports, price/cost and non-price/cost factors, etc. (de la Guardia, Molero, Valadez, 2005; Athanasoglou, Bardaka, 2010; Benkovskis, Wörz, 2017). For purposes of the research, we used a set of measures that describe four areas of competitiveness (Table 1).

Table 1. Areas and measures used for the assessment of competitiveness of export of services

\begin{tabular}{llr}
\hline \multicolumn{1}{c}{ Competitiveness areas } & \multicolumn{1}{c}{ Measures } & (Diagnostic Attributes) \\
\hline \multirow{3}{*}{ 1. General } & GDP per capita growth (annual \%) & $\left(\mathrm{X}_{1}\right)$ \\
& Annual change in productivity in services (\%) & $\left(\mathrm{X}_{2}\right)$ \\
& Services, value added (\% of GDP) & $\left(\mathrm{X}_{3}\right)$ \\
\hline \multirow{2}{*}{ 2. Price/cost } & Annual Real Effective Exchange Rates & $\left(\mathrm{X}_{4}\right)$ \\
& Nominal unit labor cost growth (\%) & $\left(\mathrm{X}_{5}\right)$ \\
\hline \multirow{3}{*}{ 3. Non-price } & Summary Innovation Index & $\left(\mathrm{X}_{6}\right)$ \\
& Knowledge-intensive services exports as \% of total services exports & $\left(\mathrm{X}_{7}\right)$ \\
& Index of Economic Freedom & $\left(\mathrm{X}_{8}\right)$ \\
\hline \multirow{3}{*}{ 4. Trade } & Annual change in share of the world export in services (\%) & $\left(\mathrm{X}_{9}\right)$ \\
& Annual growth in export (\%) & $\left(\mathrm{X}_{10}\right)$ \\
& Revealed Comparative Advantage Index (RCA) & $\left(X_{11}\right)$ \\
\hline
\end{tabular}

Source: own study based on Białowąs (2012).

The basic factors influencing the international exchange of services are economic growth and development, the importance of the services sector for economies, as well as the productivity in service sector (Francosis, Hoekman, 2010). The EU countries were recording quite volatile results regarding these measures (Table 2). 
The 2007 crisis has been reflected in the results for Ireland and the United Kingdom, however in 2015 they recorded the best results in these indicators where they were the worst in 2008.

Table 2. The best and worst values of measures of competitiveness of services export in 2008 and 2015

\begin{tabular}{|c|c|c|c|c|}
\hline \multirow{2}{*}{ Measure } & \multicolumn{2}{|c|}{2008} & \multicolumn{2}{|c|}{2015} \\
\hline & the best & the worst & the best & the worst \\
\hline GDP per capita growth (annual \%) & $\begin{array}{l}10.28 \\
\text { (RO) }\end{array}$ & $\begin{array}{l}-6.30 \\
\text { (IRL) }\end{array}$ & $\begin{array}{l}24.67 \\
\text { (IRL) }\end{array}$ & $\begin{array}{c}-0.11 \\
\text { (A) }\end{array}$ \\
\hline Annual change in productivity in services (\%) & $\begin{array}{c}23.56 \\
(\mathrm{CZ})\end{array}$ & $\begin{array}{l}-6.97 \\
\text { (UK) }\end{array}$ & $\begin{array}{l}-5.79 \\
\text { (UK) }\end{array}$ & $\begin{array}{c}-20.00 \\
(E L)\end{array}$ \\
\hline Services, value added ( $\%$ of GDP) & $\begin{array}{l}84.74 \\
\text { (LUX) }\end{array}$ & $\begin{array}{l}55.66 \\
\text { (RO) }\end{array}$ & $\begin{array}{l}87.32 \\
\text { (LUX) }\end{array}$ & $\begin{array}{l}57.33 \\
\text { (IRL) }\end{array}$ \\
\hline Annual Real Effective Exchange Rates $(2005=100)$ & $\begin{array}{l}90.45 \\
(U K)\end{array}$ & $\begin{array}{c}138.03 \\
(\mathrm{LV})\end{array}$ & $\begin{array}{l}89.74 \\
\text { (IRL) }\end{array}$ & $\begin{array}{c}130.86 \\
\text { (RO) }\end{array}$ \\
\hline Nominal unit labor cost growth (\%) & $\begin{array}{l}2.00 \\
\text { (UK) }\end{array}$ & $\begin{array}{l}21.90 \\
(\mathrm{RO})\end{array}$ & $\begin{array}{c}-16.60 \\
(\mathrm{IRL})\end{array}$ & $\begin{array}{l}7.20 \\
\text { (EE) }\end{array}$ \\
\hline Summary Innovation Index & $\begin{array}{c}0.697 \\
(\mathrm{~S})\end{array}$ & $\begin{array}{c}0.214 \\
(\mathrm{LV})\end{array}$ & $\begin{array}{c}0.704 \\
\text { (S) }\end{array}$ & $\begin{array}{l}0.180 \\
(\mathrm{RO})\end{array}$ \\
\hline Knowledge-intensive services exports as $\%$ of total services exports & $\begin{array}{l}93.05 \\
\text { (IRL) }\end{array}$ & $\begin{array}{l}17.8 \\
(\mathrm{LT})\end{array}$ & $\begin{array}{l}94.0 \\
\text { (IRL) }\end{array}$ & $\begin{array}{c}19.0 \\
\text { (CRO) }\end{array}$ \\
\hline Index of Economic Freedom & $\begin{array}{l}82.5 \\
\text { (IRL) }\end{array}$ & $\begin{array}{c}54.1 \\
\text { (CRO) }\end{array}$ & $\begin{array}{l}76.8 \\
(\mathrm{EE})\end{array}$ & $\begin{array}{l}54.0 \\
(\mathrm{EL})\end{array}$ \\
\hline Annual change in share of the world export in services (\%) & $\begin{array}{l}28.25 \\
\text { (MLT) }\end{array}$ & $\begin{array}{c}-15.14 \\
(\mathrm{UK})\end{array}$ & $\begin{array}{l}6.76 \\
\text { (IRL) }\end{array}$ & $\begin{array}{c}-20.76 \\
(E L)\end{array}$ \\
\hline Annual growth in export (\%) & $\begin{array}{c}1.49 \\
(\mathrm{MLT})\end{array}$ & $\begin{array}{l}0.99 \\
\text { (UK) }\end{array}$ & $\begin{array}{l}1.01 \\
\text { (IRL) }\end{array}$ & $\begin{array}{l}0.75 \\
\text { (EL) }\end{array}$ \\
\hline Revealed Comparative Advantage Index (RCA) & $\begin{array}{l}3.69 \\
\text { (CY) }\end{array}$ & $\begin{array}{c}0.57 \\
\text { (SVL) }\end{array}$ & $\begin{array}{c}3.47 \\
\text { (MLT) }\end{array}$ & $\begin{array}{c}0.43 \\
\text { (SVK) }\end{array}$ \\
\hline
\end{tabular}

Source: WTO (2017), Eurostat (2017), World Bank (2017), The Heritage Foundation (2017), European Commission (2017) and own calculations.

The basis for the assessment of price and cost competitiveness is the analysis of changes in real effective exchange rates and nominal unit labor costs (Białowąs, 2012). The real appreciation of the national currency causes a deterioration in the price competitiveness of domestic services on foreign markets, leading to a decline in exports over a longer period. This occurred in 2008 to all countries, except for Ireland and UK. But over the years situation changed and in 2015 in 11 countries the price competitiveness enhanced. In all countries the level of growth of the nominal costs of unit labor diminished over time what positively affected the level of price competitiveness.

Non-price factors are very important for export competitiveness and affect the growth of export to a greater extent than price and cost factors or foreign demand (European Commission, 2010). Some of them are difficult to be measured (eg. taste). Innovations, usage of advanced technologies or economic freedom are the ones that result in an increase of the competitiveness of the services export as they allow for lower operating costs, more advanced services, the development of service enterprises and expansion into international markets (Lee, 2011, The Heritage Foundation, 2017). Leaders in innovations for 2008-2015 were Sweden, Denmark, Finland and Germany, while the least innovative countries were Romania, Bulgaria and Latvia. We found out that there were three leading countries with the export share of the knowledge-intensive services (KIS) over $80 \%$ of total export of services during the whole period: Ireland, Luxembourg and UK. Two countries, Croatia and Lithuania, were the ones with the KIS 
share of less than $21 \%$. The best conditions for doing business were in Ireland, Denmark and Estonia, and the least favorable in Greece, Slovenia and Croatia.

The last group consists of indexes measuring the trade (external) competitiveness. The economic crisis of 2007-2010 has affected the trade in services of the EU countries. In 2008 export dynamics was positive for all EU countries, while in 2009 all of them (except for Malta) reported a decline in exports of services. In the following years the situation was very variable. A difficult year for service exports turned out to be 2015 , when again all the EU countries, except for Ireland, registered a negative change in share of the world services export.

The incentives for the international trade are the comparative advantage and benefits of trade for the country, enterprises and people (Lee, 2011). Differences in the availability of factors of production, skills and technological knowledge, government policies and other factors can lead to price differences and thus create incentives for trade (Copeland, Mattoo, 2008). Differentiation in these factors determine the export specialization in different types of services and is reflected in the Revealed Comparative Advantage Index (RCA). The highest rates of RCA in services in overall were reported by Luxembourg, Malta and Cyprus, while the lowest in Slovak Republic and Czech Republic.

\section{Classilication of EU countries - the method}

Due to the objective of the article, the EU countries have been compared in terms of competitiveness of export in services using the taxonomic development measures. These measures are synthetic variables that replace the description of tested objects using a set of diagnostic features by a single aggregated index (Nowak, 1990). In this study, the linear assignment of the European countries and division of typological groups of objects was made using the method based on the Weber median vector - a multi-dimensional generalization of the classical notion of the median (Młodak, 2006). The Weber median vector has the property of minimizing the sum of distances for one-dimensional data, and provides a central tendency in higher dimensions. The standardization formula using the Weber median is as follow:

$$
z_{i j}=\frac{z_{i j}-\theta_{0 j}}{1,4826 \times \operatorname{mãd}\left(X_{j}\right)},
$$

where: $\theta=\left(\theta_{01}, \theta_{02}, \ldots, \theta_{0 m}\right)$ is the Weber median, $m a \tilde{d}\left(X_{j}\right)$ is the absolute median deviation, in which the distance from the features to the Weber vector is measured, i.e.:

$$
\operatorname{mãd}\left(X_{j}\right)=\operatorname{med}_{i=1,2, \ldots, n}\left|x_{i j}-\theta_{0 j}\right|,(j=1,2, \ldots, m) .
$$

The aggregate measure is calculated with the formula:

$$
\mu_{i}=1-\frac{d_{i}}{d_{-}}, \text {and } d_{-}=\operatorname{med}(d)+2.5 \operatorname{mad}(d)
$$

where $d=\left(d_{1}, d_{2}, \ldots, d_{n}\right)$ is a distance vector calculated with the formula: $d_{i}=\operatorname{med}_{j=1,2, \ldots, m}\left|z_{i j}-\varphi_{j}\right|, \quad(i=1,2, \ldots, n)$, $\varphi_{j}=\max _{i=1,2, \ldots, n} z_{i j}$ the coordinated of the development pattern vector, which constitute of the maximum values of the normalized features. 
The assignment of objects with a positioning measure is the basis for a division of objects into four classes using the three medians method. It involves indicating a median of vector coordinates $\mu=\left(\mu_{1}, \mu_{2}, \ldots, \mu_{n}\right)$, which is denoted $\operatorname{med}(\mu)$, then dividing the population of objects into two groups: those, for which the measure values exceed the median or not. Next the indirect medians are defined as: $\operatorname{med}_{k}(\mu)=\operatorname{med}_{i: \Gamma_{i} \in \Omega_{k}}\left(\mu_{i}\right)$, where $k=1,2$.

Therefore the following groups of objects are created:

- Group I: $\mu_{1}>\operatorname{med}_{1}(\mu)$,

- Group II: $\operatorname{med}\left(\mu_{1}\right)<\mu_{1} \leq \operatorname{med}_{1}(\mu)$,

- Group III: $\operatorname{med}_{2}(\mu)<\mu_{1} \leq \operatorname{med}(\mu)$,

- Group IV: $\mu_{1} \leq \operatorname{med}_{2}(\mu)$.

Classification of the EU countries regarding competiveness of the services export by means of taxonomic methods requires specifying a set of diagnostic attributes characterizing the properties of these objects in a comprehensive way. Setting up the features merits and the limitations of data availability were taken into account. The initial list of diagnostic attributes selected for analysis consist of 11 measures (Table 1).

Due to poor diagnostic properties (coefficient of variation below 10\%), the features $X_{8}$ and $X_{10}$ were rejected. Other features were characterized by high variability (up to $450 \%$ ) and strong asymmetry. Nine of the diagnostic features proved to be stimulants, while $\mathrm{X}_{4}$ and $\mathrm{X}_{5}$ - destimulants.

\section{Results from empirical analysis}

Table 3 presents taxonomic measures of the competitiveness of service exports taking into account adopted features in the form of ranking. The data show that, in general, ranks of the particular EU countries were unstable in analyzed period. In years 2008-2015, four countries might be perceived as leaders in the competitiveness of services export: Ireland, Luxembourg, Cyprus and the United Kingdom. These countries were most often ranked in the top positions. The last places were the most often occupied by Bulgaria, Czech Republic, Lithuania and Romania. There are significant differences in rankings for other countries. The biggest divergence was noted for Estonia. A similar situation was observed for Latvia, Italy and Sweden, with differences of at least twenty positions in rankings during the years in focus.

Table 3. Competitiveness of services export ranking of the European Union Member States

\begin{tabular}{lcccccccc}
\hline \multicolumn{1}{c}{ Country } & 2008 & 2009 & 2010 & 2011 & 2012 & 2013 & 2014 & 2015 \\
\hline \multicolumn{1}{c}{1} & 2 & 3 & 4 & 5 & 6 & 7 & 8 & 9 \\
\hline Ireland & 10 & 7 & 3 & 2 & 5 & 6 & 1 & 1 \\
United Kingdom & 1 & 13 & 5 & 5 & 1 & 3 & 3 & 2 \\
Cyprus & 2 & 1 & 12 & 10 & 7 & 1 & 4 & 3 \\
Luxembourg & 16 & 3 & 1 & 1 & 2 & 2 & 2 & 4 \\
Sweden & 11 & 8 & 2 & 6 & 13 & 8 & 22 & 5 \\
Finland & 4 & 17 & 16 & 13 & 22 & 11 & 16 & 6 \\
Netherlands & 6 & 4 & 17 & 23 & 23 & 15 & 5 & 7 \\
Croatia & 20 & 23 & 26 & 14 & 20 & 20 & 18 & 8 \\
Germany & 12 & 9 & 6 & 11 & 19 & 12 & 10 & 9 \\
Greece & 7 & 5 & 14 & 17 & 3 & 4 & 16 & 9 \\
Belgium & 3 & 2 & 4 & 18 & 17 & 16 & 11 \\
Portugal & 18 & 10 & 10 & 7 & 9 & 18 & 12 & 12 \\
\hline
\end{tabular}




\begin{tabular}{|c|c|c|c|c|c|c|c|c|}
\hline 1 & 2 & 3 & 4 & 5 & 6 & 7 & 8 & 9 \\
\hline Slovenia & 17 & 21 & 22 & 24 & 25 & 22 & 19 & 13 \\
\hline Hungary & 14 & 18 & 15 & 20 & 27 & 23 & 15 & 14 \\
\hline Poland & 21 & 22 & 13 & 22 & 15 & 10 & 20 & 15 \\
\hline Malta & 13 & 6 & 7 & 15 & 24 & 5 & 6 & 16 \\
\hline Spain & 19 & 15 & 19 & 12 & 10 & 21 & 14 & 17 \\
\hline Slovak Republic & 22 & 28 & 27 & 27 & 21 & 27 & 28 & 18 \\
\hline Denmark & 9 & 19 & 9 & 16 & 4 & 7 & 11 & 19 \\
\hline France & 5 & 12 & 8 & 8 & 11 & 9 & 7 & 20 \\
\hline Czech Republic & 24 & 26 & 25 & 28 & 28 & 28 & 21 & 21 \\
\hline Austria & 15 & 14 & 18 & 9 & 12 & 14 & 17 & 22 \\
\hline Italy & 8 & 20 & 11 & 25 & 6 & 26 & 13 & 23 \\
\hline Bulgaria & 27 & 25 & 23 & 19 & 26 & 24 & 25 & 24 \\
\hline Lithuania & 23 & 24 & 24 & 21 & 14 & 25 & 27 & 25 \\
\hline Latvia & 26 & 16 & 21 & 4 & 18 & 17 & 24 & 26 \\
\hline Estonia & 28 & 11 & 20 & 3 & 8 & 19 & 23 & 27 \\
\hline Romania & 25 & 27 & 28 & 26 & 16 & 13 & 26 & 28 \\
\hline
\end{tabular}

Source: own calculations.

Taking into account the first and last year of the period, only two countries (Hungary and Latvia) have not changed their positions, what does not mean that their positions were stable throughout the period considered. It is worth noting that thirteen Member States has registered improvement of their competitiveness of export in services in 2015 compared to 2008. The best improvement was made by Croatia (by 12 positions), while the greatest a decline in rankings was experienced in France and Italy (drop by 15 positions) and Denmark (drop by 10 positions).

Using the three median method, four typology groups of the EU countries were identified regarding the competitiveness of services export (Table 4). The first group comprise of countries with the best competitiveness ranks, while the fourth one - with the lowest. In 2015 compared to 2008, half of the Member States have not changed their position in groups. For the rest of the countries, there are shifts between groups, with the six countries moving to the upper groups (increase in competiveness) and the other eight moving to the lower (worsening of the position in the ranking). It is worth noting that most countries moved within neighboring classes. Only three countries have changed their positions by two groups, with France and Italy having fallen, while Luxembourg advanced from the third to the first group.

Table 4. Typological groups of EU countries in terms of competitiveness of export in services in 2008 and 2015

\begin{tabular}{|c|c|c|}
\hline Groups & 2008 & 2015 \\
\hline 1 & United Kingdom, Cyprus, Belgium, Finland, France, Netherlands & $\begin{array}{l}\text { Ireland, United Kingdom, Cyprus, Luxembourg, Sweden, Finland, } \\
\text { Netherlands }\end{array}$ \\
\hline$\|$ & Greece, Italy, Denmark, Ireland, Sweden, Germany, Malta, Hungary & Croatia, Germany, Greece, Belgium, Portugal, Slovenia, Hungary \\
\hline III & $\begin{array}{l}\text { Austria, Luxemburg, Bulgaria, Slovenia, Portugal, Spain, Croatia, } \\
\text { Poland }\end{array}$ & $\begin{array}{l}\text { Poland, Malta, Spain, Slovak Republic, Denmark, France, Czech } \\
\text { Republic }\end{array}$ \\
\hline IV & $\begin{array}{l}\text { Slovak Republic, Lithuania, Czech Republic, } \\
\text { Latvia, Romania, Estonia }\end{array}$ & Austria, Italy, Bulgaria, Lithuania, Latvia, Estonia, Romania \\
\hline
\end{tabular}

Source: own calculations. 


\section{Conclusions}

The European Union is an organization of 28 countries with different systems, regulations and economic structures. These differences affects the countries' competitiveness of services export, which has been confirmed by the research: there is great diversity between countries, and there are no specific leaders. However, four countries (Ireland, Luxembourg, Cyprus and the United Kingdom) could be identified as such as they occupied top positions in the respective years of analysis. Other four (Bulgaria, Czech Republic, Lithuania and Romania) used to have the lowest rankings. Position of the rest of the EU Member States in the rankings were unstable and changes in ranks in some cases were quite significant.

The methods of analysis used for the purpose of the study allowed to trace changes in the competitiveness of export in services not only through the prism of individual indicators, but also by using them all together. Ranking results may raise some doubts and with different sets of indicators positions of countries might change. Therefore the further research will be focused on the set of indicators used and their significance for the analysis of the competitiveness of export in services. Secondly, the general results give a base to further more in-depth analysis of reasons for changes in ranks. And finally, in order to understand trade in services in a better way, services should be split up into specific types as the particularities of services types may affect their exchange properties in different ways.

\section{References}

Athanasoglou, P.P., Bardaka, I.C. (2010). New trade theory, non-price competitiveness and export performance. Economic Modelling, 27 (1), 217-228.

Benkovskis, K., Wörz, J. (2017). What drives the market share changes? Price versus non-price factors. Structural Change and Economic Dynamics.

Białowąs, T. (2012). Zróżnicowanie konkurencyjności a pozycja eksportowa krajów członkowskich Unii Europejskiej w handlu międzynarodowym w latach 1995-2011. In: P. Misztal, W. Rakowski (eds.), Przyszłość integracji europejskiej. Uwarunkowania rozwoju gospodarczego Unii Europejskiej (pp. 125-146). Warszawa: CeDeWu.

Copeland, B., Mattoo, A. (2008). The Basic Economics of Services Trade. In: A. Mattoo, R.M. Stern, G. Zanini (eds.), A Handbook of International Trade in Services (pp. 84-132). Oxford University Press.

de la Guardia, C.D., Molero, J., Valadez, P. (2005). International competitiveness in services in some European countries: basic facts and a preliminary attempt of interpretation. Madrit: Instituto Complutense de Estudios Internacionales, Universidad Complutense de Madrid.

European Commission (2010). Product Market Review 2010-2011. European Economy, 8.

European Commission (2017). European Innovation Scoreboard (2017). Retrieved from: http://ec.europa.eu/growth/industry/innovation/ facts-figures/scoreboards_pl (1.07.2017).

Eurostat (2017). Retrieved from: http://ec.europa.eu/eurostat/data/database (30.06.2017).

Francois, J.F., Hoekman, B. (2010). Trade and Policy in Services. Journal of Economic Literature, 48 (3), 642-492.

Freund, C., Weinhold, D. (2002). The Internet and international trade in services. The American Economic Review, 92 (2), 236-240.

Fuchs, V.R. (1968). Front matter, The Service Economy. In: The service economy (pp. 32-60). NBER.

Lee, J. (2011). Export specialization and economic growth around the world. Economic Systems, 35 (1), 45-63. DOI: 10.1016/j. ecosys.2010.11.002.

Lennon, C. (2009). Trade in Services and Trade in Goods: Differences and Complementarities, WIIW Working Papers, no. 53, April 2009.

Młodak, A. (2006). Analiza taksonomiczna w statystyce regionalnej. Warszawa: Difin.

Nowak, E. (1990). Metody taksonomiczne w klasyfikacji obiektów społeczno-gospodarczych. Warszawa: PWE.

OECD (2005). Competitiveness in International Trade. The OECD Economic Outlook: Sources and Methods. Paris. 
The Heritage Foundation (2017). Retrieved from: http://www.heritage.org (30.06.2017).

World Bank (2017). World Development Indicators and Global Development Finance. Retrieved from: http://www.worldbank.org (30.06.2017).

WTO (2017). Statistics database. Retrieved from: http://stat.wto.org (20.06.2017).

Cite this article as:. Stefaniak, J., Bak, I. (2018). Assessment of competitiveness of the EU export in services. European Journal of Service Management, 1 (25), 303-310. DOI: 10.18276/ejsm.2018.25-37. 